\title{
Cyberbullying among children and its comparison to traditional forms of peer violence
}

\author{
Nives Strabić \\ Ana Tokić Milaković \\ University of Zagreb, Faculty of Law, Department of Social Work
}

\begin{abstract}
In addition to traditional forms of peer violence (physical, verbal, relational, sexual, economic and cultural), children are increasingly involved in cyberbullying through electronic media. We present a literature review on peer violence in order to determine the similarities and specifics of cyberbullying, in comparison with traditional forms of peer violence. Similarities of these forms of bullying are manifested in the overlap of core elements in most conceptualizations of peer bullying and the correlation between being involved in the electronic and the traditional bullying perpetration, as well as in the correlation between both types of bullying victimization. On the other hand, some studies suggest that cyberbullying utterly differs from traditional forms of peer bullying in crucial elements of conceptual definitions of bullying, possible anonymity of perpetrators, wide audience and high spatio-temporal accessibility of violent content. In addition, we compare risk and protective factors for the involvement in traditional and electronic violence among peers (on individual, family, school and peer level). Despite the fact that the prevalence of traditional forms of peer victimization still exceeds the electronic forms of violence, both worldwide and in Croatia, due to cyberbullying specifics, it is essential for the current bullying prevention programs to implement certain activities specifically aiming at reducing cyberbullying among children.
\end{abstract}

Keywords: peer violence, cyberbullying, traditional forms of peer violence, risk and protective factors

\section{Introduction}

Already in early childhood, peers have an important role in the socio-emotional development of an individual (Hepler, 1997). The interaction with peers enables the development of social skills, positive attitudes, adaptive behaviours and poses an important source of social support. However, socializing with peers also often include certain undesirable outcomes, including violent behaviour among children. Certain behaviour of children can be considered bullying if it includes: (1) intentional negative actions, (2) causing harm to another child, (3) repetition and (4) the presence of power imbalance between the child perpetrating and the child exposed to aggressive behaviour (Olweus, 1998). However, violent behaviour among children does not necessarily include all these features, but children may perpetrate and experience a wider range of violent actions (Rajhvajn Bulat $\&$ Ajduković, 2012). Therefore, peer violence is considered to be a superior and broader concept than bullying and can be manifested in different ways ${ }^{12}$. Milašin, Vranić \& Buljubašić Kuzmanović (2009) distinguish physical (e.g., hitting, pushing, spitting), verbal (teasing, name calling, etc.), relational (e.g. social exclusion and the spreading of rumours about another person), sexual (e.g., unwanted physical contact of sexual nature), economic (such as expropriation and extortion of money) and

1 Despite the frequent interchangable use of the terms of violence and abuse among children in domestic and foreign literature, this paper will use both terms as they are mentioned by authors in original papers, but efforts will be made to respect the aforementioned difference between them (both in the traditional and in the electronic modality). 
cultural violence (such as insults on national, religious or other prohibited grounds). According to the visibility of violent acts, the mentioned forms of traditional violence can be overt or covert (Velki \& Kuterovac Jagodić, 2014).

Due to the continuous advancement of technology, the possibilities of communication and interaction among children are being expanded. Although electronic media are becoming extremely popular in this population, their use bears certain risks. Children and young people can very easily be subjected to violations of their rights in the virtual sphere, such as the right to privacy or the right to protection from potentially harmful information and contents (Pezo, 2010). Everyday peer violence spreads to virtual space through electronic media, creating the so-called cyberbullying. Cyberbullying can be defined as intentional and repeated violent action directed towards a child via computers, mobile phones and other media (Patchin \& Hinduja, 2015).

The involvement of children in virtual violent behaviour is also manifested in different ways (Baum, 2007, Willard, 2007) such as: (1) harassment, i.e. repeated sending of abusive or harassing messages, and their posting in locations visible to the wider "audience", (2) cyberthreats directed to another person, groups or self-addressed, (3) denigration, i.e. the spread of false and harmful information about a person or alteration of someone's photos (aiming to harm the reputation of a person), (4) flaming, which involves provoking conflict by sending various offensive or vulgar messages, (5) impersonation i.e. decrypting of passwords for various profiles (e.g. on social networks) and the use of someone else's or false identity (for the purpose of sending or publishing compromising contents about others), (6) outing and trickery of information that become available to the general public by exposure (with the aim of embarrassing and dishonouring a person), (7) exclusion, which is reflected by denying access to specific sites or groups on social networks and intentional blocking an individual from different lists of online friends, (8) cyberstalking, i.e., repeated sending of threatening or harassing messages resulting in a person's fear for their own safety.

Since cyberbullying is a relatively new modality of violent behaviour, available literature often starts from the context in which traditional forms of peer violence are taking place, along with the analysing of specific characteristics of cyberbullying (Erdur-Baker, 2010). Accordingly, the aim of this paper is to compare cyberbullying to the traditional forms of peer violence, namely through the presentation of a conceptual discussion about their similarities and specificities in modern professional and scientific literature and by comparing their prevalence, forms and correlates (potential risk and protective factors).

\section{Conceptual comparison of traditional peer violence and cyberbullying among children and their prevalence}

A consensus on the relationship between traditional bullying and cyberbullying among children has not yet been fully achieved. Some authors consider bullying a unique phenomenon (e.g. Beran \& Li, 2007, Mehari, Farell \& Le, 2014), while cyberbullying is considered only a continuation of traditional violent behaviour, i.e. a new modality of the same phenomena. In doing so, they use elements of the definition of traditional bullying to define cyberbullying (Mehari et al., 2014). In order to consider children's behaviour as bullying, whether it takes place in the immediate interaction or in a virtual environment, it is important that it includes repeated aggressive actions with 
the intention to cause harm, and where imbalance of power between the child perpetrating and the child experiencing such actions occur. Thus, both phenomena meet the basic criteria of bullying to a certain extent (Olweus, 1998). In this sense, cyberbullying among children can be considered as one of indirect forms of aggressive treatment that does not take place in "face to face" interaction (as is the case with traditional relational bullying), but by means of electronic media (Beran \& Li, 2007).

Furthermore, the equivalence of traditional bullying and cyberbullying is manifested in compliance of roles of children involved in both modalities of bullying ( $\mathrm{Li}, 2005$ Modecki et al., 2014). Hence, children perpetrating traditional bullying are also prone to committing cyberbullying. Also, children who are exposed to traditional forms of bullying often experience cyberbullying as well. Young people who simultaneously perpetrate and experience traditional bullying, also commit violent actions in the virtual environment and are at the same time exposed to them (Li, 2005). Similar to traditional peer violence which can be witnessed by peers, messages or comments can be posted in a public virtual domain and be available to acquaintances or strangers of children involved in bullying. In other words, the role of the "audience" in the virtual space is to some extent comparable to the role of peers and bystanders in school or on the street (Beran $\&$ Li, 2007).

Other authors are less inclined to consider peer violence as a unique phenomenon and emphasize primarily the specificity of cyberbullying in relation to traditional forms of peer violence among children (e.g. Dooley, Pyżalski \& Cross, 2009, Slonje, Smith \& Frisen, 2012). Thus, Patchin \& Hinduja (2015) discuss the aforementioned elements of the definition of bullying when it occurs through electronic media. Since the intention of the "perpetrator" is the key element that distinguishes bullying from random incidents on the Internet, viewing this component from the perspective of the person experiencing bullying is questionable. In fact, a person will sometimes perceive that bullying to which he/she is exposed to, is committed with intent, even when this is not the case (Patchin \& Hinduja, 2015). For example, someone can comment a picture or other content in jest, but due to the absence of non-verbal communication, the person who is being commented on can see this as a provocation or insult.

Also, the element of harm as a result of cyberbullying is essential, but sometimes less obvious and recognizable in a virtual environment (Vandebosch \& Van Cleemput, 2008). Considering the fact that children prone to perpetration of cyberbullying cannot see the person they harm nor the consequences of such behaviour, Patchin \& Hinduja (2015) believe that is not justified to view the harm from the perspective of young people who bully, because they are usually prone to rationalisation and minimisation of the consequences of their actions.

Furthermore, due to the nature of virtual environment, there is a certain probability of repetition of violence (Patchin \& Hinduja, 2015). In doing so, only one post with violent content on the Internet can contribute to the repeated experience of violence of the person exposed to it every time this person is online.

The last component of bullying involves imbalance of power, which in traditional bullying is manifested in physical, psychological or social superiority of the child prone to bullying in relation to the child at which such behaviour is directed. By contrast, the superiority of the child acting violently through electronic media derives from IT knowledge and skills and the possession or access to content which is purposed to cause harm (Patchin \& Hinduja, 2015). Thus, the superiority of a 
child in a virtual environment can be expressed through the control of topics in discussions on the Internet, causing conflicts by sending virtual messages with inappropriate content or higher status in virtual communities (Shariff \& Gouin, 2006, Menesini \& Nocentini, 2009).

In addition to problematisation of these components of the definition of bullying, some authors emphasize some differences between traditional bullying and cyberbullying (e.g. Heirman \& Walrave, 2008). When it comes to traditional forms of peer violence, the identity of the child perpetrating violence is usually known to the peer to whom such behaviour is directed and others which may be in the vicinity of the aggressive actions (Greene, 2006). Therefore, there is a possibility to provide timely protection to the child who is victimized, by other people who witness violent incidents. Due to potential anonymity of interactions in virtual context, the identity of the child perpetrating violence may remain unknown and undiscovered to the child to which the aggressive actions are directed. Slonje et al. (2012) claim that children who perpetrate cyberbullying, but are not revealed nor faced with the consequences of their behaviour, tend to pursue the aggressive acts. On the other hand, a child who is subjected to virtual violence finds it difficult or sometimes impossible to discover whether it is abused by one or more persons, an acquaintance or a stranger, etc., which increases the level of experienced emotional stress (Heirman \& Walrave, 2008). In addition, the anonymity of the "perpetrator" can lead to limited possibility for timely and adequate intervention of adults or the child subjected to aggressive behaviour, and prevention of such actions in the future (Slonje et al., 2012).

Furthermore, the role of the "audience" witnessing virtual violence is more complex compared to the one of traditional violence (Slonje et al., 2012). Traditional forms of peer violence can take place without the presence of "observers" or in front of a relatively limited group of children who directly witness aggressive behaviour (Heirman \& Walrave, 2008). However, by means of information and communication technologies, the same acts of violence perpetrated by a child at one time (e.g. posting of compromising content on the Internet) can at any time later be reviewed, discussed or distributed by another person who had previously witnessed such act, thus also assuming the role of the cyberbullying "perpetrator" (Slonje et al., 2012).

If the context of peer violence is observed, traditional violence is usually considered the problem of school environment, which mainly takes place in front of peers at school or on the way home (Beran \& Li, 2007). Also, in traditional forms of peer violence a child is exposed to harmful behaviour exclusively in a momentary spatial and temporal context (Burton, Florell \& Wygant, 2013). On the other hand, violent behaviour in a virtual environment generally goes beyond the context of school and the street (Greene, 2006). Such violent actions take place without physical interaction and can be manifested at any time, permanently exposing the child at which they are aimed (Heirman \& Walrave, 2008, Burton et al., 2013).

Regarding the prevalence of peer violence, it is generally considered a relatively widespread phenomenon. Wang, lannotti \& Nansel (2009) claim that young people in the United States are mostly involved in verbal (53.6\%) and social (51.4\%) bullying, followed by physical bullying (20.8\%) and cyberbullying (13,6\%). In Germany, traditional bullying is also more prevalent in comparison to cyberbullying, which involves about $5 \%$ of children (Riebel, Jäger \& Fischer, 2009). Accordingly, Smith et al. (2008) point out that traditional bullying in England still surpasses cyberbullying in 
prevalence, but a general increase in cases of cyberbullying is also evident. Similarly, in a study conducted on a representative sample of seventh-graders in Croatia (Pećnik \& Tokić, 2011), 73\% of participants said that they committed some forms of physical violence (hitting or slapping) in the past year, about $50 \%$ of them conducted verbal (swearing and insults) and relational bullying (spreading rumours), while about $20 \%$ of children perpetrated some forms of cyberbullying (compromising one's reputation through the Internet).

\section{Risk and protective factors of children's involvement in traditional peer violence and cyberbullying}

Long-term involvement in peer violence may result in adverse effects on the overall functioning and well-being of the individual. Also, certain individual characteristics may be identified as risk and/or protective factors for the involvement of children in violent behaviour. Risk and protective factors on individual, family, academic and peer level will be analyzed ${ }^{23}$ hereafter. Risk factors, i.e. factors that increase the likelihood of children's involvement in peer violence, are situated in a complex interaction with internal and external strengths of a child, that buffer the risks and act as protective factors (Lösel \& Farrington, 2012).

\subsection{Individual risk and protective factors}

In the domain of individual factors one of the most widely studied characteristics of children involved in bullying is the sex of the child. Some studies show that boys more often perpetrate traditional bullying than girls (Olweus, 1998, Erdur-Baker, 2010). For example, Khamis (2015) finds that traditional bullying was perpetrated by $21.5 \%$ of boys compared to $14.2 \%$ of girls in the past two months. A possible exception may be relational peer violence (Pećnik \& Tokić, 2011), although certain findings suggest that boys use relational aggression to a roughly similar extent as girls (Delveaux \& Daniels, 2000). When it comes to the peer victimization, it is assumed that boys are more at risk than girls (Erdur-Baker, 2010, Griezel et al., 2012). This statement is illustrated by the results of the mentioned research (Khamis, 2015), which show that in the past two months, boys (21.8\%) were more often exposed to traditional bullying than girls (18.0\%). Findings on the existing sex differences in experiencing peer victimization are confirmed by Silva et al. (2013), stating that boys are more often "victims" of all forms of traditional peer violence, except for relational peer victimization, where girls prevail.

When it comes to perpetrating cyberbullying, some authors believe that boys, compared to girls, are also more prone to act aggressively in a virtual environment ( $\mathrm{Li}, 2006$, Erdur-Baker, 2010, Wang et al., 2009). Also, recent studies have determined the existence of sex differences in perpetrating cyberbullying in favour of boys (Deniz, 2015). On the other hand, some authors do not determine sex differences in the perpetration of cyberbullying and state that boys and girls engage almost equally in peer violence (Slonje \& Smith, 2008, Beckman, Hagquist \& Hellström, 2013). Some authors believe that girls are more often involved in violent acts on the Internet than boys, explaining this with the tendency of girls to engage in indirect forms of violence (Kowalski \& Limber, 2007). The results for cyber-victimization are also inconsistent. In fact, some authors argue

2 Factors on social level are also important (for example, the environment that presents violence as a generally accepted form of behaviour may constitute a risk factor for the involvement of children in violence), but they will not be covered by this paper. 
that boys (as with traditional forms of violent behaviour) are more often exposed to cyberbullying than girls (Erdur-Baker, 2010, Deniz, 2015, Wong, Chan \& Cheng, 2014). On the other hand, there are studies that do not find sex differences and suggest that boys and girls are at about the same risk of experiencing cyberbullying (Li, 2006), or that girls are even more often in the role of the "victim" of cyberbullying (Slonje et al., 2012, Beckman et al., 2013, Wang et al., 2009). Since there are adverse findings, some authors suggest that sex is a less relevant predictor of children's involvement in cyberbullying (García Fernández, Romera Félix \& Ortega Ruiz, 2015). It is also possible that boys are more prone to certain forms of violence in the virtual environment (e.g. flaming), while some other forms (e.g. outing and trickery) may be more common in girls, but this hypothesis should be tested empirically.

Considering the physical appearance of the child, it is suggested that children who are physically stronger than others (Olweus, 1998), as well as overweight and obese children (Kukaswadia, 2009) often engage in perpetrating traditional forms of peer violence. Accordingly, Janssen et al. (2004) argued that peer violence is somewhat more often perpetrated by overweight (11.2\%) and obese (9.2\%) children than children with ideal body weight, based on the ratio of height and weight of an individual (8,3\%). On the other hand, children with a physique weaker than that of other children (Olweus, 1998), as well as overweight and obese children (DeSmet et al., 2014) are usually at risk of peer victimization. For example, by comparing groups of children according to body weight, research of Janssen et al. (2004) shows that overweight (14.4\%) and obese (18.5\%) children are more frequently exposed to traditional forms of peer victimization than children with ideal body weight (10.7\%). In addition to weight, young people are often exposed to bullying due to the appearance of their teeth (Al-Bitar, et al., 2013) and various skin diseases such as acne or dermatitis (Magin, 2013).

Taking into account the characteristics of physical appearance in case of cyberbullying, young people who act violently in the virtual sphere do not necessarily have to be physically stronger or more attractive compared to their peers. If they perpetrate cyberbullying due to physical appearance, they focus on children who wear specific clothing, glasses or stand out in some other way (Berne, Frisén \& Kling, 2014). Cassidy, Jackson \& Brown (2009) state that children often experience cyberbullying on the basis of body weight, actual or perceived sexual orientation and dressing style. At the same time, girls are predominantly subjected to offensive comments on the Internet concerning their excess body weight and physique, clothing or makeup, and boys due to pronounced feminine characteristics, dressing style and physical appearance, with frequent referring to homosexual orientation or lack of muscle mass (Frisén \& Berne, 2014 Berne et al., 2014).

As for developmental specifics, children with certain developmental difficulties are more likely to react violently towards their peers in a state of frustration. Thus, some authors argue that children diagnosed with the Attention Deficit Hyperactivity Disorder (hereinafter: ADHD) tend to perpetrate traditional violence among peers (Taylor et al., 2010). Consistently, Holmberg \& Hjern (2008) state that traditional forms of peer violence are more often perpetrated by children who show symptoms of ADHD (20.8\%) compared to children without diagnosed developmental difficulties (7.0\%). Studies also show that children with ADHD (Olweus, 1998), as well as children with autistic spectrum disorders (Schroeder et al., 2014) and other developmental disabilities belong to risk groups for peer victimization. For example, by studying the exposure to traditional bullying 
based on the presence of ADHD symptoms, Holmberg \& Hjern (2008) found that somewhat more children with ADHD symptoms (32.5\%) were exposed to occasional bullying compared to children without developmental disabilities (15.0\%), and the differences were even more noticeable when it came to experiencing frequent bullying (2.0\% of children without and $31.8 \%$ of children with ADHD symptoms).

Like traditional peer violence, children with ADHD often perpetrate violence in the virtual environment as well (Yen et al., 2014). Also, children with specific intellectual disabilities are prone to violent activities on the Internet (Didden et al., 2009). By comparing groups of children on the basis of the developmental stage, Heiman \& Olenik-Shemesh (2015) found that compared to typically developing children $(8.7 \%)$, cyberbullying is somewhat more often perpetrated by children with developmental difficulties included in regular school programmes (12,1\%), and even more often by children with developmental difficulties who attend special classes (20.7\%). Similar to traditional forms of peer violence, children with ADHD and children with autistic spectrum disorders more often experience virtual violence (Good \& Fang, 2015). Also, children with learning disabilities are often subjected to cyberbullying (Eden, Heiman \& Olenik-Shemesh, 2013). Overall, it appears that certain peculiarities in child development may be relevant predictors of children's participation in violent behaviour, regardless of the modality of violence.

Following the presentation of risk factors, some protective factors for the involvement in peer violence should be mentioned. These are higher level of intelligence, high level of prosocial behaviour, as well as the absence of ADHD symptoms and children's depression and anxiety (Lösel \& Bender, 2013). Also, Wachs (2012) indicates that a reduction of perpetrating traditional peer violence and cyberbullying among children is primarily the result of the empathy development and the reduction of the moral distance from the "victim" of peer violence. In addition, higher self-esteem of the child, developed skills of constructive conflict resolution and lower experience of social isolation help children exposed to peer victimization in dealing with aggressive acts (Sapouna \& Wolke, 2013). Furthermore, a high level of emotional control that implies the ability of a child to refrain from negative reactions (e.g., anger, fear or sadness) to the experienced peer violence has proven to be an important protective factor for traditional and cyber-victimization (Hemphill et al., 2014). When it comes to cyberbullying specifically, avoiding encounters with strangers met by children on the Internet contributes to the protection of children and the prevention of their involvement in cyberbullying (Wachs, Wolf \& Pan, 2012). In addition, Vandebosch, Poels \& Deboutte (2014) state that children's awareness about the importance of adequate ways of responding to cyber-victimization (e.g. selecting the privacy settings, preserving the evidence and sharing the experience about cyberbullying to adults) is extremely important in situations of their exposure to violent behaviours.

\subsection{Family risk and protective factors}

In addition to personal predictors, factors in the family of the child, especially the quality of the relationship with parents, represent important predictors of peer violence. Growing up in families with pronounced and frequent conflicts between family members, as well as in overly protective families is brought in connection with the perpetration of traditional peer violence (Figula et al., 2011), as well as exposure of the child to the authoritarian parenting style, which is rigid and lacks 
adequate level of responsiveness and support (Georgiou et al., 2013). On the other hand, exposure of children to psychological aggression (Gómez-Ortiz, Romera \& Ortega-Ruiz, 2015) or abuse and neglect by parents (guardians) is associated with the peer victimization at school (Boel-Studt $\&$ Renner, 2014 ). Also, children whose parents have a permissive upbringing style are at a somewhat greater risk of exposure to peer victimization compared to other children (Georgiou, 2008).

When it comes to perpetrating cyberbullying, deficiencies or avoidance of communication between the child and the parents or the family in general are associated with the child's tendency for perpetrating cyberbullying (Floros et al., 2013). As with traditional forms of peer violence, authoritarian parenting style is associated with the commission of cyberbullying (Floros et al., 2013). Furthermore, it was shown that frequent punishment or excessive indulgence of parents are correlated with perpetration, but also exposure to cyberbullying (Velki \& Kuterovac Jagodić, 2014). Makri-Botsari \& Karagianni (2014) find that the authoritarian and neglecting parenting style, compared to the permissive or authoritarian parenting style, are associated with an increased likelihood of children's exposure to cyberbullying, which is consistent with the finding that lower responsiveness by parents is associated with cyber-victimization (Dehue et al., 2012).

As for the protective factors in the family, a strong connection among family members and open communication about the children's problems are negatively associated with the child's engagement in peer violence and positively correlated with the likelihood that a child prone to perpetrating violence will change his/her behaviour over time (Duggins et al., 2016). In addition, consistent parenting practices (Lösel \& Bender, 2013) and parental warmth (Karlsson et al., 2014, Dehue et al., 2012) represent the protective factors from perpetrating and experiencing peer violence. Also, acknowledging children's opinions (in accordance with his/her age and maturity) the exchange of ideas between parents and children, and familiarity of parents with the child's friends reduce the likelihood of children's involvement in traditional peer violence and cyberbullying (Shetgiri, Lin \& Flores, 2013). Furthermore, the pronounced connection with parents helps children exposed to peer victimization to cope with that experience in a constructive way (Duggins et al., 2016), primarily by confiding in parents (Hemphill et al., 2014). In addition, the availability of support within the family can lead to a reduced risk of cyber-victimization, especially in the absence of support of friends (Fanti, Demetriou \& Hawa, 2012).

Literature that links parental practices and the risk of children's participation in cyberbullying often emphasizes the importance of adequate parental monitoring, particularly during adolescence when parents generally decrease their involvement in supervising the child's Internet use (Krmek, Buljan Flander \& Hrpka, 2007). Thus You, Kim \& Kim (2014) found a correlation between inadequate level of parental monitoring and adolescent tendency to behave violently towards others in a virtual environment. It is also noted that a relatively small number of parents installs filters or programmes for a safe use of the Internet in order to protect children (Levine, 2013). In addition, it seems that parents systematically overestimate the level of their supervision over the Internet use by their children. Thus Wang, Bianchi \& Raley (2005) report that only $61 \%$ of parents state that there are clear rules about using the Internet in their family, of which in fact one third is denied by statements of their adolescents, who report that such rules do not exist. Also, the operationalization of parental monitoring in studies was questioned recently (Stattin \& Kerr, 2000), because the existing scales of monitoring were actually measuring parental knowledge of child's whereabouts 
out of parents' sight. Stattin \& Kerr (2000) showed that this knowledge is mainly acquired by free and spontaneous self-disclosure of the child, and not by parental monitoring efforts (Stattin \& Kerr, 2000). Accordingly, it was found that active parental monitoring strategies over the use of electronic media (such as sitting at the computer with the adolescent, checking visited web sites and use of security filters) are not really correlated with the involvement of the child in different risky behaviours on the Internet (for a review see Liau, Khoo \& Ang, 2008). In case of overly restrictive rules and supervision over the use of the Internet at home, it is very likely that adolescents will access the Internet from other places such as a friend's home or a cafe with Internet access (Khoo et al., 2006, according to Liau et al., 2008). Thus, instead of direct parental monitoring, it is more important to improve and maintain open communication with adolescents about the use of the Internet (Liau et al., 2008).

\subsection{Risk and protective factors in the school and peer environment}

With the mentioned dispositions of the child and characteristics of the family environment, various factors in the context of school can contribute to the involvement of children in violent behaviour. When it comes to the connection between academic achievement and the perpetration of traditional forms of peer violence, some studies show that a weaker academic achievement of the student (Ma et al., 2009, Bradshaw et al., 2013, Kowalski \& Limber, 2013) and a negative perception of own academic competence (Ma et al., 2009) are associated with violent actions. On the other hand, children who achieve better academic results than other students often experience peer victimization, probably due to the other pupils' envy of their academic achievement (van der Werf, 2014). Also, the exposure to violent behaviour usually leads to decreasing of academic achievement over time (Espelage et al., 2013, van der Werf, 2014).

As in the case of traditional peer violence, children who use violent patterns of behaviour on the Internet usually achieve lower results in school compared to their peers (Kowalski \& Limber, 2013, Selak Bagarić et al., 2014). Accordingly, Mitchell (2011) found that children with higher academic achievement will probably perpetrate cyberbullying to a lesser extent, but are also victimized less often. Also, lower academic achievement is usually associated with becoming the "victim" of cyberbullying (Twyman et al., 2010). Specifically, Beran \& Li (2007) explain that difficulties in fulfilling school duties lead to increased exposure to teasing, ridicule and other violent actions of children, both in school and by means of electronic media. However, lower academic achievement of the child can also occur as a result of cyber-victimization (Ryan \& Curwen, 2013).

Poor affection to school is also a risk factor for peer violence in school. Namely, Swearer (2002, according to Alika, 2012) states that young people who perpetrate peer violence are prone to different risk activities (e.g. avoiding classes) which can indirectly lead to school retention. Also, avoiding school and ultimately dropping out of the education system has been associated with peer victimization in school (Alika, 2012).

In accordance with the findings in the domain of perpetrating traditional forms of peer violence, absence from school and premature leaving of school due to health reasons or grades are associated with violent actions of young people in the virtual sphere (Kowalski \& Limber, 2013). 
Also, children who are exposed to cyberbullying on an ongoing basis are largely refusing to go to school, compared to children who do not experience cyberbullying (Pregrad et al., 2010).

As far as peer relations are concerned, Velki \& Vrdoljak (2013) point out that children prone to perpetrating violent actions have a great number of friends, though they are often not popular among their peers. In addition, they usually socialize with peers who encourage their aggressive behaviour. Furthermore, weaker social adjustment of a child in the peer context represents a risk factor for perpetrating, but also for experiencing traditional forms of peer violence (García Fernández et al., 2015).

As for cyberbullying, it was found that peers who tolerate violent reactions face-to-face, contribute to a child's tendency to behave the same in the virtual sphere (Festl, Scharkow \& Quandt, 2013). Similarly, friends in a virtual environment (e.g. on social networks) can easily assume the role of the "bystander" of cyberbullying, and their encouragement or support of violent actions on the Internet can contribute to violent online behaviour (Dodge et al., 2006, according to Hemphill $\&$ Heerde, 2014). As with traditional peer victimization, a poor relationship with peers leads to a greater likelihood of cyber-victimization (Slonje \& Smith, 2008). However, some recent studies failed to found that a poorer social adjustment of the child in the peer context is a predictor of perpetrating cyberbullying (García Fernández et al., 2015). In addition, children with a larger number of friends on Facebook who regularly distribute posts with negative content are also at increased risk of experiencing cyberbullying themselves (Peluchette et al., 2015).

Considering the protective factors in the school and peer context, Puzić, Baranović \& Doolan (2011) state that adequate supervision of teachers and other school associates is an important source of support to school children in conflict resolution. Relying on the mentioned research results in the area of parental monitoring and adolescent adjustment (Stattin \& Kerr, 2000), it should be noted that this supervision should be based on open and two-way communication and a good relationship between teachers and pupils. Clear rules in the classroom and supportive climate, training of teachers on the importance of violence prevention, regular communication between teachers and parents as well as practicing student team work in schools, also contribute to the reduction of children's involvement in violent behaviour (Ttofi \& Farrington, 2011). In addition, a powerful sense of belonging to the school can help the child not to respond with aggressive actions to peer victimization, but with constructive conflict resolution strategies (Duggins et al., 2016). Also, good teaching, supervising the execution of school tasks and behaviour, and concern for students by their teachers contribute to a reduced involvement of children in bullying (Karlsson et al., 2014). Furthermore, a supportive school climate increases the willingness of children to engage in violence prevention programmes and encourages them to turn to adults in case of involvement in bullying (Selak Bagarić et al., 2014).

\section{Conclusion}

The question whether cyberbullying is just one form of traditional bullying or a new phenomenon cannot be answered unambiguously, but an overview of conducted studies comparing these forms of violence among children indicates certain similarities of cyberbullying with traditional forms of peer violence, and certain specifics as well. 
First of all, the similarity of these forms of violent behaviour among children is indicated by an overlap of the key elements of the definition, where bullying (either direct or by means of electronic media) involves repeated violent behaviour perpetrated with the intention of causing harm, with an imbalance of power between the child that perpetrates and the one that experiences such action (Mehari et al., 2014). In addition, some authors argue that the context of traditional peer violence and cyberbullying is not different, but that violence in the virtual sphere is an additional modality of indirect bullying (Beran \& Li, 2007). Also, the similarity of this phenomena is reflected in the correlation between perpetrating traditional bullying and cyberbullying and between experiencing both forms of bullying (Modecki et al., 2014), which often means that the same individuals perpetrate and experience both forms of bullying. Furthermore, certain individual characteristics of a child are consistently protective/risk factors for the occurrence of traditional forms and cyberbullying. Thus overweight and obese children (DeSmet et al., 2014, Berne et al., 2014), and children with autistic spectrum disorders (Schroeder et al., 2014, Good \& Fang, 2015) are at risk of peer victimization regardless of the modality, while children with ADHD tend to perpetrate and experience both types of violence among peers (Taylor et al., 2010, Yen et al., 2014).

On the other hand, protective factors from perpetrating traditional forms of peer violence and cyberbullying among children proved to be developed empathy and reduction of moral distance from the "target" of violence (Wachs, 2012), while high emotional control is a relevant protective factor from the experience of both modalities of victimization (Hemphill et al., 2014).

While an authoritarian parenting style proved to be an important predictor of perpetrating traditional peer violence and cyberbullying (Georgiou et al., 2013, Floros et al., 2013), and the experience of both forms of bullying is associated with the experience of neglect by parents (BoelStudt \& Reiner 2014, Makri-Botsari \& Karagianni, 2014), open and two-way communication in the family and familiarity of parents with the child's friends are suggested to be important protective factors from the children's participation in both modalities of peer violence (Shetgiri et al., 2013).

Considering school and peer factors, children who are perpetrating traditional peer violence and cyberbullying have lower academic achievement (Bradshaw et al., 2013, Kowalski \& Limber, 2013), poorer school affection (Alika, 2012, Kowalski \& Limber, 2013) and friends who encourage aggressive behaviour (Velki \& Vrdoljak, 2013, Festl et al., 2013). Children with poorer quality of relationships with friends are at risk of peer victimization (Slonje $\&$ Smith, 2008). Also, if a climate of violent reaction is dominant in the classroom, it will also be transmitted to the virtual domain (Festl et al., 2013). In contrast, a supportive school climate is a key protective factor from the involvement of children in violent behaviour, regardless of the modality of bullying (Ttofi \& Farrington, 2011, Selak Bagarić et al., 2014).

Despite the determined similarities, some authors emphasize the particularities of cyberbullying and point out that it differs from the traditional forms of peer violence in certain aspects. Patchin \& Hinduja (2015) believe that key characteristics of abuse (intention, recurrence, damage, imbalance of power) are differently manifested when it comes to traditional peer violence and cyberbullying among children. In addition, the anonymity of the "perpetrator", "mass" audience, and accessibility of harmful content to everyone and at all times, are the characteristics specific to cyberbullying and differentiate it from traditional peer violence (Heirman \& Walrave., 2008). 
In addition, the participation of children in traditional forms of peer violence is related to specific temporal and spatial context (Burton et al., 2013), while cyberbullying goes beyond and can be manifested at any time (Greene, 2006). Research in Croatia and international research suggest that cyberbullying is still represented less than traditional forms of peer violence (e.g. Pećnik \& Tokić, 2011, Riebel et al., 2009). As for the individual factors that contribute to the involvement of children in violence, it was shown that boys perpetrate (Khamis, 2015, Deniz, 2015) and experience traditional peer violence more often than girls (Griezel et al., 2012, Deniz, 2015), except in case of relational violence. When it comes to cyberbullying, the findings are quite inconsistent, which may indicate a need to take into account the different forms of violence in the virtual environment (e.g. flaming can be more characteristic for boys, and outing and trickery for girls). As far as physical appearance is concerned, children who perpetrate traditional forms of peer violence usually have a stronger physique (Olweus, 1998), which does not have to apply to cyberbullying (Berne et al., 2014) where the superiority of a child perpetrating peer violence, compared to the one experiencing it, is reflected in the possession of IT knowledge, skills or the availability of compromising content etc. (Patchin \& Hinduja, 2015). Considering the factors related to the context of school, children with better school achievement are at a somewhat greater risk of traditional peer victimization (van der Werf, 2014), and those with lower scores in school often experience cyberbullying (Beran \& Li, 2007). In addition, a weaker social adjustment of children in the peer context is found to be associated with the perpetration of traditional peer violence, but not with the perpetration of cyberbullying (García Fernández et al., 2015).

With regard to the identified meeting points of traditional peer violence and the omnipresent cyberbullying, it may be assumed that the existing methods of prevention of bullying that are implemented in many schools (for a review see Velki \& Ozdanovac, 2014) will also have a certain effect on the prevention of cyberbullying. However, the highlighted specifics of cyberbullying indicate the need for special attention to that form of violence and include specific measures in existing programmes, which would be aimed at decreasing violence that occurs outside the usual space-time frame in which traditional peer violence is taking place. It is vital to raise wider public awareness about the incidence of such type of bullying, constant professional training of experts who work with children (particularly in schools, as well as in other relevant institutions for children), adequate co-operation of competent authorities and active involvement of children and their parents/guardians in all stages of prevention.

\section{References}

al-Bitar, Z. B., Al-Omari, I. K., Sonbol, H. N., Al-Ahmad, H. T., Cunningham, S. J. (2013): Bullying among Jordanian school children, its effects on school performance, and the contribution of general physical and dentofacial features. American Journal of Orthodontics \& Dentofacial Orthopedics. 144 (6). 872-878.

Alika, H. I. (2012): Bullying as a Correlate of Dropout from School among Adolescents in Delta State: Implication for Counselling. Education. 132 (3). 523-531.

Baum, S. (2007, studeni): Cyberbullying: a Virtual Menace. Rad izložen na Nacionalnoj konferenciji protiv nasilja, Melbourne. 
Beckman, L., Hagquist, C., Hellström, L. (2013): Discepant gender patterns for cyberbullying and traditional bullying - An analysis of Swedish adolescent data. Computers in Human Behavior. 29 (5). 1896-1903.

Beran, T., Li, Q. (2007): The Relationship between Cyberbullying and School Bullying. Journal of Student Wellbeing. 1 (2). 15-33.

Berne, S., Frisén, A., Kling, J. (2014): Appearance-related cyberbullying: A qualitative investigation of characteristics, content, reason, and effects. Body image. 11 (4). 527-533.

Boel-Studt, S., Renner, L. M. (2014): Child and family-level correlates of direct and indirect peer victimization among children ages 6-9. Child Abuse \& Neglect. 38 (6). 1051-1060.

Bradshaw, C., Waasdorp, T., Goldweber, A., Johnson, S. (2013): Bullies, Gangs, Drugs, and School: Understanding the Overlap and the Role of Ethnicity and Urbanicity. Journal of Youth \& Adolescence. 42 (2). 220-234.

Burton, A. K., Florell, D., Wygant, D. B. (2013): The Role of Peer Attachment and Normative Beliefs about Aggression on Traditional Bullying and Cyberbullying. Psychology in the Schools. 50 (2). 103-115.

Cassidy, W., Jackson, M., Brown, K. N. (2009): Sticks and Stones Can Break My Bones, But How Can Pixels Hurt Me? Students' Experiences with Cyber-Bullying. School Psychology International. 30 (4). 383-402.

Dehue, F., Bolman, C., Vollink, T., Pouwelse, M. (2012): Cyberbullying and Traditional Bullying in Relation to Adolescents' Perception of Parenting. Journal of CyberTherapy \& Rehabilitation. 5 (1). 25-34.

Delveaux, K. D., Daniels, T. (2000): Children's Social Cognitions: Physically and Relationally Aggressive Strategies and Children's Goals in Peer Conflict Situations. MerrillPalmer Quarterly. 46 (4). 672-692.

Deniz, M. (2015): A Study on Primary School Student's Being Cyber Bullies and Victims According to Gender, Grade, and Socioeconomic Status. Croatian Journal Educational. 17 (3). 659-671.

DeSmet, A., Deforche, B., Hublet, A., Tanghe, A., Stremersch, E., De Bourdeaudhuij, I. (2014): Traditional and cyberbullying victimization as correlates of psychosocial distress and barriers to a healthy lifestyle among severely obese adolescents-a matched case-control study on prevalence and results from a cross sectional study. BMC Public Health. 14 (224). 1-12.

Didden, R., Scholte, R. H., Korziliius, H., de Moor, J. M. H., Vermeulen, A., O'Reilly, M., Lang, R., Lancioni, G. E. (2009): Cyberbullying among students with intellectual and developmental disability in special education settings. Developmental Neurorehabilitation. 12 (3). 146-151.

Dooley, J. J., Pyżalski, J., Cross, D. (2009): Cyberbullying Versus Face-to-Face Bullying: A Theoretical and Conceptual Review. Journal of Psychology. 217 (4). 182-188.

Duggins, S. D., Kuperminc, G. P., Henrich, C. C., Smalls-Glover, C., Perilla, J. L. (2016): Aggression among adolescent victims of school bullying: Protective roles of family and school connectedness. Psychology of Violence. 6 (2). 205-212.

Eden, S., Heiman, T., Olenik-Shemesh, D. (2013): Teachers' perceptions, beliefs and concerns about cyberbullying. British Journal of Educational Technology. 44 (6). 10361052. 
Erdur-Baker, Ö. (2010): Cyberbullying and its correlation to traditional bullying, gender and frequent and risky usage of intenet-mediated communication tools. New Media \& Society. 12 (1). 109-125.

Espelage, D. L., Hong, J. S., Rao, M. A., Low, S. (2013): Associations Between Peer Victimization and Academic Performance. Theory Into Practice. 52 (4). 233-240.

Fanti, K. A., Demetriou, A. G., Hawa, V. V. (2012): A longitudinal study of cyberbullying: Examining risk and protective factors. European Journal of Developmental Psychology. 9 (2). 168-181.

Festl, R., Scharkow, M., Quandt, T. (2013): Peer Influence, Internet use and Cyberbullying: A Comparison of Different Context Effects among German Adolescents. Journal of Children \& Media. 7 (4). 446-462.

Figula, E., Margitics, F., Pauwlik, Z., Szatmári, A. (2011): School bullying: background factors of the victims, bulllies, bully/victims in family socialization. Mentálhigiènè ès Psichoszomatika. 12 (1). 47-72.

Floros, G., Paradeisioti, A., Hadjimarcou, M., Mappouras, D. G., Kalakouta, O., Avagianou, P., Siomos, K. (2013): Cyberbullying in cyprus-Associated parenting style and psychopathology. Studies in Health Technology and Informatics. 191. 85-89.

Frisén, A., Berne, S. (2014., svibanj): Appearance related cyberbullying-A problem especially for girls. Rad izložen na Konferenciji: Cyberbullying: A Challenge for Researchers and Practitioners, Gothenbur.

García Fernández, C. M., Romera Félix, E. M., Ortega Ruiz, R. (2015): Explicative factors of face-toface harassment and cyberbullying in a sample of primary students. Psicothema. 27 (4). 347-353.

Georgiou, S. (2008): Parental style and child bullying and victimization experiences at school. Social Psychology of Education. 11 (3). 213-227.

Georgiou, S., Fousiani, K., Michaelides, M., Stavrinides, P. (2013): Cultural value orientation and authoritarian parenting as parameters of bullying and victimization at school. International Journal of Psychology. 48 (1). 69-78.

Gómez-Ortiz, O., Romera, E. M., Ortega-Ruiz, R. (2015): Parenting styles and bullying. The mediating role of parental psychological aggression and physical punishment. Child Abuse \& Neglect. DOI: 10.1016/j.chiabu.2015.10.025.

Good, B., Fang, L. (2015): Promoting Smart and Safe Internet Use Among Children with Neurodevelopmental Disorders and Their Parents. Clinical Social Work Journal. 43 (2). 179-188.

Greene, M. B. (2006): Bullying in Schools: A Plea for Measure of Human Rights. Journal of Social Issues. 6 (1). 63-79.

Griezel, L., Finger, L. R., Bodkin-Andrews, G. H., Craven, R. G., Yeung, A. S. (2012): Uncovering the Structure of and Gender and Developmental Differences in Cyber Bullying. Journal of Educational Research. 105 (6). 442-455.

Heiman, T., Olenik-Shemesh, D. (2015): Cyberbullying Experience and Gender Differences Among Adolescents in Different Educational Settings. Journal of Learning Disabilities. 48 (2). 146-155. 
Heirman, W., Walrave, M. (2008): Assessing Concerns and Issues about the Mediation of Technology in Cyberbullying. Cyberpsychology: Journal of Psychosocial Research on Cyberspace. 2 (2). 1-18.

Hemphill, S. A., Heerde, J. A. (2014): Adolescent Predictors of Young Adult Cyberbullying Perpetration. Journal of Adolescent Health. 55 (4). 580-587.

Hemphill, S. A., Tollit, M., Kotevski, A., Heerde, J. A. (2014): Predictors of Traditional and CyberBullying Victimization: A Longitudinal Study of Australian Secondary School Students. Journal of Interpersonal Violence. 30 (15). 1-24.

Hepler, J. B. (1997): Social Development of Children: The Role of Peers. Children \& Schools. 19 (4). 242-256.

Holmberg, K., Hjern, A. (2008): Bullying and attention-deficit-hyperactivity disorder in 10-yearolds in a Swedish community. Developmental Medicine \& Child Neurology. 50 (2). 134-138.

Janssen, I., Craig, W. M., Boyce, W. F., Pickett, W. (2004): Associations Between Overweight and Obesity With Bullying Behaviors in School-Aged Children. Pediatrics. 113 (5). 11871194.

Karlsson, E., Stickley, A., Lindblad, F., Schwab-Stone, M., Ruchkin, V. (2014): Risk and protective factors for peer victimization: a 1-year follow up study of urban American students. European Child \& Adolescent Psychiatry. 23 (9). 773-781.

Khamis, V. (2015): Bullying among school-age children in the greater Beirut area: Risk and protective factors. Child Abuse \& Neglect. 39. 137-146.

Kowalski, R. M., Limber, S. P. (2007): Electronic Bullying Among Middle School Students. Journal of Adolescent Health. 41 (6). 22-30.

Kowalski, R. M., Limber, S. P. (2013): Psychological, Physical, and Academic Correlates of Cyberbullying and Traditional Bullying. Journal of Adolescent Health. 53 (1). 13-20.

Krmek, M., Buljan Flander, G., Hrpka, H. (2007): Nasilje među vršnjacima Internetom. [Cyberbullying] U Kolesarić V. (ur.), Psihologija i nasilje u suvremenom društvu. Osijek: Sveučilište Josipa Jurja Strossmayera, Filozofski fakultet. 125-132.

Kukaswadia, A. A. (2009): Social Consequences of Obesity among Canadian Youth. Doktorska disertacija. Kingston. Ontario: Queen's University.

Levine, E. L. (2013): A Study of Parental Understanding of and Intervention in Cyberbullying among Children in Fourth through Eight Grade. Doktorska disertacija. Indiana. University of Pennsylvania.

Li, Q. (2005): New bottle but old wine: A research of cyberbullying in schools. Computers in Human Behavior. 23 (4). 1777-1791.

Li, Q. (2006): Cyberbullying in Schools: A Research of Gender Differences. School Psychology International. 27 (2). 157-170.

Liau, A. K., Khoo, A., Ang P. H. (2008): Parental Awareness and Monitoring of Adolescent Internet Use. Current psychology. 27 (4). 217-233.

Lösel, F., Bender, D. (2013): Aggressive, Delinquent, and Violent Outcomes of School Bullying: Do Family and Individual Factors Have a Protective Function?. Journal of School Violence. 13 (1). 59-79. 
Lösel, F., Farrington, D. P. (2012): Direct Protective and Buffering Protective Factors in the Development of Youth Violence. American Journal of Preventive Medicine. 43 (2). 8-23.

Ma, L., Phelps, E., Lerner, J. V., Lerner, R. M. (2009): The development of academic competence among adolescents who bully and who are bullied. Journal of Applied Developmental Psychology. 30 (5). 628-644.

Magin, P. (2013): Appereance-related bullying and skin disorders. Psychodermatology. 31 (1). 66-71.

Makri-Botsari, E., Karagianni, G. (2014): Cyberbullying in Greek Adolescents: The Role of Parents. Procedia - Social and Behavioral Sciences. 116. 3241-3253.

Mehari, K. R., Farell, A. D., Le, A. T. H. (2014): Cyberbullying Among Adolescents: Measures in Search of a Construct. Psychology of Violence. 4 (4). 399-415.

Menesini, E., Nocentini, A. (2009): Cyberbullying definition and measurement: Some critical considerations. Journal of Psychology. 217 (4). 230-232.

Milašin, A., Vranić, T., Buljubašić Kuzmanović, V. (2009): Ispitivanje učestalosti verbalne agresije kod djece i mladeži. [Research on incidence of verbal aggression in children and youth] Život i škola. 55 (22). 116-141.

Mitchell, M. S. (2011): Cyberbullying and Academic Achievement: Research into the Rates of Incidence, Knowledge of Consequences, and Behavioral Patterns of Cyberbullying. Doktorska disertacija. University of Connecticut.

Modecki, K. L., Minchin, J., Harbaugh, A. G., Guerra, N. G., Runions, K. C. (2014): Bullying Prevalence Across Contexts: A Meta-analysis Measuring Cyber and Traditional Bullying. Journal of Adolescent Health. 55 (5). $602-611$.

Olweus, D. (1998): Nasilje među djecom u školi.[Bullying at school] Zagreb. Školska knjiga.

Patchin, J. W., Hinduja, S. (2015): Measuring cyberbullying: Implications for research. Aggression and Violent Behavior. 23. 69-74.

Pećnik, N., Tokić, A. (2011): Roditelji i djeca na pragu adolescencije: pogled iz tri kuta, izazovi i podrška. [Parents and children on the threshold of adolescence: view from three angles, challenges and support] Ministarstvo obitelji, branitelja i međugeneracijske solidarnosti, Zagreb.

Peluchette, J. V., Karl, K., Wood, C., Williams, J. (2015): Cyberbullying victimization: Do victims' personality and risky social network behaviors contribute to the problem?. Computers in Human Behavior. 52. 424-435.

Pezo, A. (2010): Uloga odraslih u zaštiti djece na Internetu. [The role of adults in protection of children on the Internet] U Jelavić M. (ur.), Dječja prava i slobodno vrijeme. Pravobranitelj za djecu, Zagreb. 79-86.

Pregrad, J., Tomić Latinac, M., Mikulić, M., Šeparović, N. (2010): Iskustva i stavovi djece, roditelja i učitelja prema elektroničkim medijima. [Experiences and attitudes of children, parents and teachers toward electronic media] Ured UNICEF-a za Hrvatsku, Zagreb.

Puzić, S., Baranović, B., Doolan, K. (2011): Školska klima i sukobi u školi. [School climate and conflicts in school] Sociologija i prostor. 49 (3). 335-358. 
Rajhvajn Bulat, L., Ajduković, M. (2012): Obiteljske i psihosocijalne odrednice vršnjačkoga nasilja među mladima. [Family and Psychosocial Determinants of Youth Peer Violence] Psihologijske teme. 21 (1). 167-194.

Riebel, J., Jäger, R. S., Fischer, U. C. (2009): Cyberbullying in Germany- an exploration of prevalence, overlapping with real life bullying and coping strategies. Psychology Science Quarterly. 51 (3). 298-314.

Ryan, K. N., Curwen, T. (2013): Cyber-Victimized Students: Incidence, Impact, and Intervention. SAGE Open. 3 (4). $1-7$.

Sapouna, M., Wolke, D. (2013): Resilience to bullying victimization: The role of individual, family and peer characteristics. Child Abuse \& Neglect. 37 (11). 1-10.

Schroeder, J., Cappadocia, M., Bebko, J., Pepler, D., Weiss, J. (2014): Shedding Light on a Pervasive Problem: A Review of Research on Bullying Experiences Among Children with Autism Spectrum. Journal of Autism \& Developmental Disorders. 44 (7). 15201534.

Selak Bagarić, E., Buljan Flander, G., Hrpka, H., Tomić, J., Bilić, V. (2014., studeni): Uloga podržavajuće školske klime u prevenciji elektroničkog nasilja. [The role of supportive school climate in the prevention of cyberbullying] Rad izložen na XXII. Godišnjoj konferenciji hrvatskih psihologa: Kako obrazovanju dodati boju? - uloga i izazovi za psihologe, Rovinj.

Shariff, S., Gouin, R. (2006): Cyber-Dilemmas: Gendered Hierarchies, New Technologies and Cyber-Safety in Schools. Atlantis. 31 (1). 27-37.

Shetgiri, R., Lin, H., Flores, G: (2013). Trends in risk and protective factors for child bullying perpetration in the United States. Child Psychiatry \& Human Development. 44 (1), 89-104.

Silva, M. A. I., Pereira, B., Mendonça, D., Nunes, B., Oliveira, W. A. (2013): The Involvement of Girls and Boys with Bullying: An Analysis of Gender Differences. International Journal of Environmental Research and Public Health. 10 (12). 6820-6831.

Slonje, R., Smith, P. K. (2008): Cyberbullying: Another main type of bullying?. Scandinavian Journal of Psychology. 49 (2). 147-154.

Slonje, R., Smith P. K., Frisen, A. (2012): The nature of cyberbullying, and strategies for prevention. Computers in Human Behavior. 29 (1). 26-32.

Smith, P. K., Mahdavi, J., Carvalho, M., Fisher, S., Shanette, R., Tippett, N. (2008): Cyberbullying: Its Nature and Impact in Secondary School Pupils. Journal of Child Psychology and Psychiatry. 49 (4). 376-385.

Stattin, H., Kerr, M. (2000): Parental monitoring: a reinterpretation. Child Development. 71 (4). 1072-1085.

Taylor, L. A., Saylor, C., Twyman, K., Macias, M. (2010): Adding insult to injury: bullying experiences of youth with attention deficit hyperactivity disorder. Children's Health Care. 39 (1). 59-72.

Ttofi, M. M., Farrington, D. P. (2011): Effectiveness of school-based programs to reduce bullying: a systematic and meta-analytic review. Journal of Experimental Criminology. 7 (1). 27-56. 
Twyman, K., Saylor, C., Taylor, L. A., Comeaux, C. (2010): Comparing Children and Adolescents Engaged in Cyberbullying to Matched Peers. Cyberpsychology, Behavior, and Social Networking. 13 (2). 195-199.

Van der Werf, C. (2014): The Effects of Bullying on Academic Achievement. Desarrollo y Sociedad. 74. 278-308.

Vandebosch, H., Poels, K., Deboutte, G. (2014): Schools and Cyberbullying: Problem Perception, Current Actions and Future Needs. International Journal of Cyber Society and Education. 7 (1). 29-48.

Vandebosch, H., Van Cleemput, K. (2008): Defining Cyberbullying: A Qualitative Research into the Perceptions of Youngsters. Cyberpsychology \& Behavior, 11(4), 499-503.

Velki, T., Kuterovac Jagodić, G. (2014): Individualni i kontekstualni činitelji dječjega nasilničkoga ponašanja prema vršnjacima. [Individual and contextual factors of peer violence] Ljetopis socijalnog rada. 21 (1). 33-64.

Velki, T., Ozdanovac, K. (2014): Preventivni programi usmjereni na smanjenje vršnjačkog nasilja u osnovnim školama na području Osječko-baranjske županije. [Bullying prevention programs in primary schools in Osječko-baranjska county] Školski vjesnik-Časopis za pedagogijsku teoriju i praksu. 63 (3). 327-352.

Velki, T., Vrdoljak, G. (2013): Uloga nekih vršnjačkih i školskih varijabli u predviđanju vršnjačkoga nasilnog ponašanja. [The Role of Some Peer and School Variables in Prediction of Peer Violence] Društvena istraživanja. 22 (1). 101-120.

Wachs, S. (2012): Moral disengagement and emotional and social difficulties in bullying and cyberbullying: differences by participant role. Emotional and Behavioural Difficulties. 17 (3-4). 347-360.

Wachs, S., Wolf, K. D., Pan, C. (2012): Cybergrooming: Risk factors, coping strategies and associations with cyberbullying. Psicothema. 24 (4). 628-633.

Wang, J., lannotti, R. J., Nansel, T. R. (2009): School Bullying Among Adolescents in the United States: Physical, Verbal, Relational, and Cyber. Journal of Adolescent Health. 45 (4). 368-375.

Wang, R., Bianchi, S. M., Raley, S. B. (2005): Teenagers' Internet Use and Family Rules: A Research Note. Journal of Marriage and Family. 65 (5). 1249-1258.

Willard, N. (2007): Cyberbullying and Cyberthreats: Responding to the Challenge of Online Social Aggression, Threats and Distress. Champaign. Research Press.

Wong, D. S. W., Chan, H. C. O., Cheng, C. H. K. (2014): Cyberbullying perpetration and victimization among adolescents in Hong Kong. Children andYouth Serveces Review. 36. 133-140.

Yen, C., Chou, W., Liu, T., Ko, C., Yang, P., Hu, H. (2014): Cyberbullying among male adolescents with attention-deficit/hyperactivity disorder: Prevalence, correlates, and association with poor mental health status. Research in Developmental Disabilites. 35 (12). 3543-3553.

You, S., Kim, E., Kim, M. (2014): An Ecological Approach to Bullying in Korean Adolescents. Journal of Pacific Rim Psychology. 8 (1). 1-10. 